\title{
"A Study of Role in Financing of Agricultural and Industrial Sect ors by State Bank of India with Special Reference to Bihar (In Recent Years)"
}

\author{
Dr. Kumudani Mangal \\ Dept. of Economics Somnath - Gujarat
}

\begin{abstract}
The role of state bank in agricultural and Industrial finance was very negligible till very recently Stat e Banks branch network had a strong urban basis and did not have an adequate coverage of rural areas. Keepin $g$ this fact in view Government took a bold step of nationalizing the 14 Banks in 1969 in order to reduce the regi onal imbalances. The advances of State Bank of India towards a agricultural and Industrial Development are al so Increased enormously. Instead it has started new type of branches at important Centers known as State Bank of India Agricultural Development Banks. The bank (SBI-ADB) with the available resources and by the assistan ce from the NABARD has been assisting the potential farmers. Involvement of State Bank of India in agricultura $l$ and Industrial finance in a big way is said to be a boon to the agriculturists and Industrialist. Moreover SBI ar e providing finance for farming, Industry, and other related activities which is a gate way for the prosperity of $t$ he made to the examine the working of SBI to special of Bihar.
\end{abstract}

\section{Major objectives of the study}

1 To examine the role of the state bank of India in agricultural and Industrial finance with special reference of Bihar.

2 To analyses the Impact of the finance on the sample borrowers, cropping pattern, income and employment levels in Bihar.

3 To examine the adequacy of credit provided for different schemes in Bihar.

4 To examine the repayment performance of the sample borrower farmers and Businessman of Bihar.

5 To examine the opinions of the borrowers on the finance extended by the State Bank of India.

6 To suggest ways and means for improving the operational efficiency of bank branches in financing the rural sector with special reference to State bank of India, Bihar.

7 To analyses the reasons for over dues in State bank of India to overcome the over dues in the bank

8 To examine Important causes for non-repayment of the loans are :- (a) lack of supervision by the bank, (b) Crop failure, (c) Impression that bank loans are like subsidies granted by government which need not to be repaid, etc.

\section{Need for the study}

A study to examine the Impact of the State banks finance in rural development. The problems of both $t$ he banker and farmer and gave suggestions to overcome the problems. It is also a known fact that the State Bank of India took initiative in opening separate branches for financing agricultural and Industrial development. Ther e are no systematic studies on the working of State Bank of India with specific references to branches in Bihar o ur study may also helps in understanding the working of SBI from the point view of its beneficiaries. This micro level study may helps in bringing out the changes helps in making suggestions of the empirical study.

\section{Summary}

State bank of India is the oldest and one of the largest commercial bank in India. It is serving the peopl e more than 200 years back. The bank provides a full range of corporate commercial and retail banking services in India. Indian central bank namely Reserve Bank of India (RBI) is the major share holder of the bank with 59. $7 \%$ stake. The bank is capitalized to the extent of Rs. 646 on with the public holding (other than promoters) at 4 $0.3 \%$ SBI has largest branch and ATM network spread across every corner of India The bank has a branch netw ork of over 14,000 branches (including subsidiaries) A part from Indian network it also has a network of 73 over seas offices in 30 countries in all time zones, correspondent relationship with 520 international bank in 123 coun tries. It caters to the needs of agriculturists and laud less agricultural laborer through a network of 8750 rural and same urban branches. A part from the branches, there are 428 agricultural development branches (ADBS) whic $\mathrm{h}$ also cater to agriculturists (www.sbi.com).

State bank of India have covered a whole gamut of agricultural activities like crop production, horticult ure, plantation crops, farm mechanization, land development and reclamation, digging of wells, tube wells and ir 
rigation projects, forestry, construction of cold storages and god owns, processing of agri- products finance to ag ri-Input dealers, allied activities like dairy fisheries, poultry, sheep-goat, piggery and rearing of silk worms. SBI has schemes and products both for short term requirements as well as long term requirements of agriculturists. " kisan credit card (KCC) is a popular package to cover the short term requirement of the farmers carrying four co mponents of their requirement Viz-crop production requirement, ancillary requirements like repair and maintena nce of pump sets, pipeline, purchase small implements of couple of farm animals and contingent need that may arise during ". (www.sbi.com)

\section{Suggestion}

The need to support the agricultural and Industrial sectors has been well recognized and the efforts in th is direction have been enormous and institutions set up to aid this sector are aplenty. For in Bihar it is essential $\mathrm{t}$ o support the agricultural and Industrial sectors. Although the efforts in this direction has been made enormously and many institution set up to aid this sector. The problems faced by the people of Bihar broadly relate to inabil ities to understand and take advantage of various facilities available from commercial banks, regional rural bank s, co-operative banks, local area banks government agencies, self help groups and micro finance institution. Thei $r$ problems arise from the absence of steady income, high institutions in the prices of their products, high level of inflammation, increased Inputs cost undependable infrastructure such as electricity, transport, marketing, and st orage facilities and grant of initiatives a good beginning

SBI is the largest banking sector of India which fulfils the agricultural and industrial needs of the count ry by reviewing the literature it is obvious that net much work has been done on the roll of SBI credit in Bihar.

1) The banks should appoint such officials who to the people of remote areas and make them aware about the framing and business policies of the bank in their own languages. This will make the farmers directly interacted with the bank its policies.

2) The procedure of section of lone should be easy the number of documents required for it should be as less as possible.

3) The banks should have to launch the campaign for the awareness of bank policies in the remote villages.

4) The bank should provide the knowledge about new technologies under joint program with the help of IERT and scientists and engineers.

5) Additional credit union should be set up in the localities.

6) The Training for transaction with the ATM or KCC and online pay tm card should be provided to the public.

7) The bank should have to launch the awareness program to make people aware about the guidelines and policies.

8) To analyze the SBI credit benefit on farmers and industrialists development.

9) To analyze the problem faced by the public in borrowing from the state bank of India.

\section{Findings}

The bank should appoint such officials who go to the investors of remote areas and make them award a bout the agricultural policies of the bank in their own languages this will make a farmers directly interacted with the bank it's polices. The procedure of sanction of loan should be easy i.e. the numbers of document required fo $r$ it should be as less as possible The bank should have to launch the campaign for the awareness of bank policie $\mathrm{s}$ in the remote villages The findings of this study show that, the higher the interest rates the lower the demand $\mathrm{f}$ or loans. In addition high interest rates cripple framing business that is high interest rates tends to have an advers e effect on the development or growth of framing or business in Bihar, since they depend very much on availabil ity and accessibility fund at reasonable or favorable rates.

\section{Conclusion}

For a developing country, It essential to support the banking sectors. Although the efforts in this directi on has been made enormously and many institution set up to aid this sectors. The banking sectors is considered as the back bone of our economy but unfortunately it is still gambling on monsoon and dependent on informal cr edit. The problems faced by the villagers broadly relate to inabilities to understand and lake advantage of variou $\mathrm{s}$ facilities available from commercial banks, regional rural banks, Co -Operative banks, local area banks, gover nment agencies self help groups and micro finance institution. Their problem arise from the absence of steady in come, high fluctuations in the prices of their products, high level of inflation, increased inputs cost undependabl e Infrastructure such as electricity, transport, marketing and stored rural storage facilities, Basically developmen $\mathrm{t}$ of agriculture and industrial sector is state subject. Hence the imitative and leadership would have to come fro $\mathrm{m}$ the states.

SBI is the largest banking sector of India which fulfils the agricultural needs of the country. By reviewi ng the literature it is obvious that not much work has been done on the role of SBI credit in Bihar. The introducti 
on of agricultural and Industrial developments based on which allocation of resources and grant of initiatives by the central government can be made and perhaps it is a good beginning. All data collected through face to face $i$ nteraction with villagers and interview with BANK MANAGER, by meeting them impersonal and questionnaire $\mathrm{s}$, needed. The data used for their study are inclusive of the data collected from internet, and brochures, magazin es and articles. The convenient sampling method was used in article.

Also, it is a study of variables in their natural setting or under usual circumstances. This comprises obse rvation of facts, formulation of hypothesis, collection and classification of data, interpretation of data, formulati on of theories, application of facts and predictions. Since human behavior is difficult and cannot be predicted, it makes the results of the research at times not to be applicable to the population. The questionnaires were used in order to get a standard form of answers or survey in Bihar.

\section{References}

[1] Dr. Prasoon kumar Roy (HOD in Economics) Bihar university, Bihar.

[2] Prof. Jaimangal Pd Shama (Department of Economics) Magadh University.

[3] Annual Report 2010-2011 (Ministry Of Finance, Government of India).

[4] State Level Banker's Committee of Bihar-2010-2011 (A Report).

[5] The Economic times.

[6] The Times of India.

[7] www.wikkipedia.com

[8] www.RBI.ORG.IN.

[9] www.brandbihar.com

[10] www.sbi.com

[11] Yojana-2009, 2010, 2011, 2012.

[12] World Bank report, 2011-12. 